\title{
Major Activities of Light Electric Scooter Development in Taiwan
}

\author{
Bing Ming Lin*, Mo Hua Yang**, Theresa Suan***, ITRI
}

\begin{abstract}
Taiwan has more than 13 million registered motorcycles. EPA set the mandate of $2 \%$ electric motorcycle to be sold in 2000 and subsidized consumers to buy those clean vehicles were proved not successful and stopped. A smaller, lighter styling electric scooter was then becoming more or less popular in countryside may be categorized as "Small Light Motorcycle" in near future. This article briefly reviews the development of electric scooter during past years and focus on the status, too. There are some new developments of electric scooter with different hybrid concepts show good potential are also introduced.
\end{abstract}

\section{Keywords: Scooter, Demonstration, Hybrid strategy, Lithium-ion battery, Promotion}

\section{PREFACE}

Like many other tropical and subtropical area countries, with the similar temperature, traffic condition and industrialize progressing, Taiwan has over thirteen million engine scooters (or motorcycles) registered on road. As the world number three in production volume of 1.44 million, forty-five percent of them were exported in 2005, Taiwan adopted phase four emission regulation from 2004 which measures emission from cold start and two-stroke engine scooter is hardly able to survive. Most of the $50 \mathrm{cc}$ light scooters used to be two-stroke disappeared quickly, but four-stroke $50 \mathrm{cc}$ scooters are not performing as good as two-stroke, market share of $50 \mathrm{cc}$ is dropping quickly from over $35 \%$ down to less than $10 \%$. Drivers need to pass road test to get driving license for scooters over 50cc, many people give up riding scooters because they are afraid of taking the road test.

While constructing public transportations and encouraging people to use them are always the first priority in solving traffic and pollution problem of urban area, people in Taiwan tends to use two-wheeled vehicle to access to near destinations for shopping, picking up children, connecting between public transportation or even the office and home due to limited parking place and congested traffic. Although the emission of engine scooters has been cutting down gradually during these years, the huge amount of them driving on road is still considered the major contribution of urban pollution. Government promoted electric scooter during last decade and found not successful, it seems also hard to run electric scooter business everywhere in the world, those which are still

\footnotetext{
* Material and Chemical Research Laboratories, Industrial Technology Research Institute, Bldg. 77, 195-5 Chung Hsing Rd., Section 4, Chutung, Hsinchu, Taiwan 31015, bmlin@itri.org.tw

** mhyang@itri.org.tw *** Theresasuan@itri.org.tw
}

in the business struggle to find their way out. Adding the effect of high energy price today, will people reconsider the vehicle of comparably short in performance, high in price? Is the battery technology and price proved acceptable? Are there new concepts attract people change their way of commuting? On the way of light electric vehicle (LEV) industry development, China has a very peculiar market, over ten million of electric-scooter-like electric bikes are sold in 2005 and is increasing dramatically every year. Like other commodities, China sucks the investment and resources from other areas including Taiwan. Some Taiwan major players has set up their manufacturing centers in China and tend to design LEV for China market, then export back to Taiwan by modifying the styling and performance since the LEV market size is comparably tiny in Taiwan. Will Taiwan lose competitiveness disregarding its strong manufacturing infrastructure and design capability developed during past forty years? Industrial Development Bureau (IDB) of Ministry of Economic Affairs (MOEA) keeps sponsoring electric scooter promotion activities to find if there is a market existing in the near future while EPA is looking forward to seeing the possibility of reducing green house gas emission by using electric scooters.

\section{REVIEW OF PAST EXPERIENCES}

Taiwan has been devoting in electric scooter business during last decade with many resources from government, academics, research institutes and industries. First electric scooter developed by Kang Yang debut in 1993, the performance was far behind engine scooter however, much expectation was put on this kind of vehicle which might solve motorcycle pollution problem in the future. Not before the second one's launch, EPA started subsidizing for buying 
electric scooter from 1995 and gradually increased the subsidy to drive the market. The highest amount of subsidy was around USD1000 at the end of year 1999. Vehicles had to pass a series test on vehicle and components to get various level of subsidies.

An aggressive promotion program was passed by Executive Yuan in 1997[1] to project three million electric scooters on road, EPA set $2 \%$ mandate of electric scooter sales from year of 2000. A Strategic Alliance Motor company was therefore organized by traditional scooter makers to manufacture electric scooter as a supporting to government policy. Charge station construction could also be subsidized if qualified by review committee. A 150 electric scooters fleet demonstration was held during 1997 1999, thirty-three academic units participated in promoting those vehicles and educating the public.

Feasibility of battery swap and quick charge were studied to see if they can be adopted to further boost up the amount of vehicle. Since the batteries were all lead acid and weighing near $40 \mathrm{~kg}$, a demonstration swap machine was built to exchange the batteries semiautomatically, battery box was modified to a movable device, it could be shifted to a storage rack waiting for charging. Various business models with prediction of vehicle amount, advanced batteries technology and gasoline price and so on were all reviewed to see if it is commercial feasible. We found it requires an initial investment of one billion and takes ten years to get even[2]. Twenty electric scooters of four different models were modified to quick chargeable by replacing wiring, adding monitoring circuit and charging sockets. Five sets of quick charger[3] which could deliver $3 \mathrm{~kW}$ peak power were expected to charge the batteries from $20 \%$ to $80 \%$ SOC in fifteen minutes. Those scooters were fleet tested to see the operating convenience and effect on battery cycle life.

All those activities did not really boost up the market. The subsidy ended by 2002, over 27,000 electric scooters made by seven companies got subsidy from government (Figure 1). By optimistic estimation, there are still $3000 \sim 8000$ of them in operation, EPA sponsors a project to take care of those vehicles since most of the original manufacturers do not exist any more, EPA needs to find necessary replacing components for those users who are really the props. Subsidiary policy is not the best way of promoting electric vehicle, we need to find the products which is truly marketable. Table 1[4] is to review deficiencies of previous work, it is hard to condemn "who killed the electric scooters", batteries, engine scooter makers, government, dealers, infrastructure and electric scooter itself were either considered to take the responsibility. It seems hybrid is an alternative solution and looks optimistic in the near futrue for passenger cars. Is it also true for electric scooter to adopt hybrid concept? Have those problems listed in Table 1 been solved nowadays by which the industry will have a new era?

\section{ELECTRIC SCOOTER SUBSIDIARY QUANTITY}

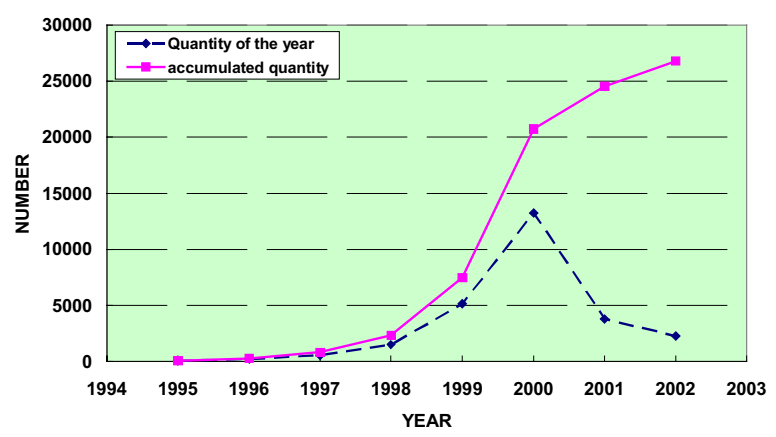

Fig. 1 Electric scooter subsidiary quantity

Table 1 Deficiencies of previous work

\begin{tabular}{|c|c|}
\hline Vehicle technology & Sale \\
\hline $\begin{array}{l}\text { - Difficult to compete with } \\
\text { engine scooter in } \\
\text { performance } \\
\text { - Reliability and cost issue } \\
\text { of battery } \\
\text { - Heavy in weight } \\
\text { - Some poor product image } \\
\text { and reliability } \\
\text { - Incidents }\end{array}$ & $\begin{array}{l}\text { - Traditional scooter retailer } \\
\text { don't support } \\
\text { - Lack sale channels for new } \\
\text { makers } \\
\text { - Exaggerative in } \\
\text { performance data } \\
\text { - Too small market, hard to } \\
\text { invest on product } \\
\text { improvement or new } \\
\text { design }\end{array}$ \\
\hline Infrastructure & Promotion \\
\hline $\begin{array}{l}\text { - Limited charge } \\
\text { infrastructure, hard to } \\
\text { find plug place for most } \\
\text { apartment residents } \\
\text { - Lack of maintenance } \\
\text { infrastructure and } \\
\text { capability, very slow } \\
\text { replacement and repair }\end{array}$ & $\begin{array}{l}\text { - Too aggressive planning in } \\
\text { the beginning } \\
\text { - Strong opposition from } \\
\text { traditional scooter makers } \\
\text { on } 2 \% \text { sales mandate }\end{array}$ \\
\hline
\end{tabular}

\section{RECENT ACTIVITIES}

Other than looking after the props by EPA, IDB takes the responsibility for the continuation of electric scooter industry development from 2000, EVT Technology Co. is still supplying product (Figure 2), after years of improvement, it is considered one of the most reliable products in the same grade, eGO (Figure 3) is another one of world famous made in Taiwan by Helio Technologies Co., though only few of them are sold in Taiwan. Some works or programs are still ongoing locally, waiting for another era's coming.

Thanks to the progress of advanced technologies such as lithium-ion battery, in virtue of its high power and energy density, swapping the battery or charging it in house become feasible, the charging infrastructure will not be an issue any more. Better management of battery pack gives battery longer cycle life and more accurate indication of charge state. Vehicle also becomes lighter and easy to handle. The current issues are mostly related to safety and cost only, it requires new idea or business model to sell and promote 
such vehicles.

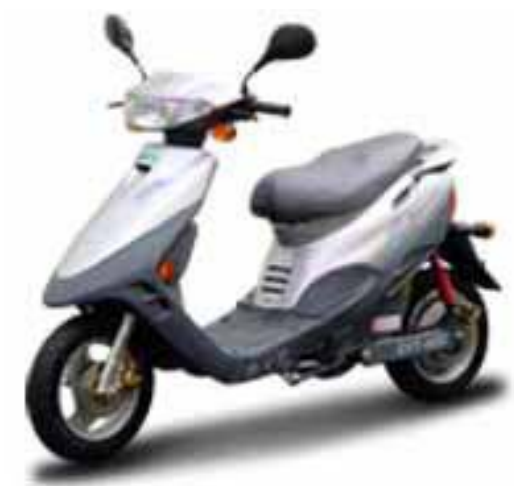

Fig.2 EVT Technology electric scooter

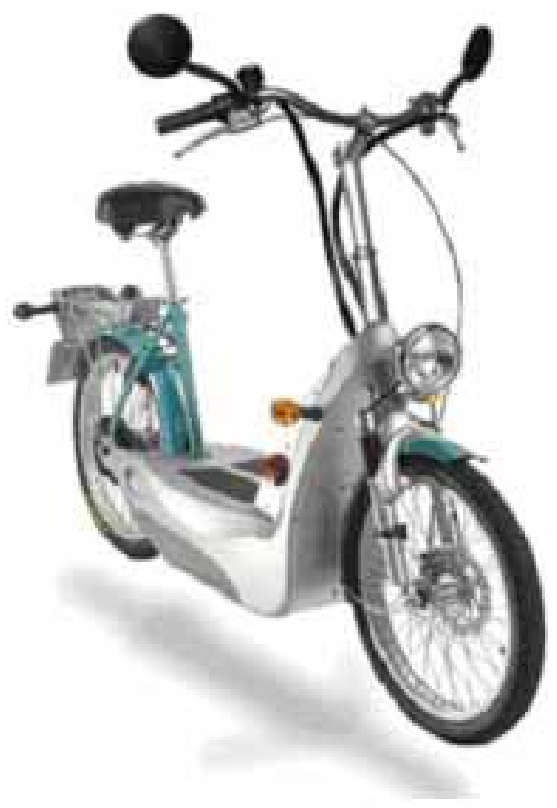

Fig. 3 eGO electric scooter

\subsection{Public Segment Projects and Promotion Works}

\subsubsection{Small Light Motorcycle Legalization}

This is the most important and controversy subject during past three years. Wheeled ski-board with handle bar was once very popular worldwide, power unit and batteries were then added and also the seat and becoming fancier (Figure 4).

Most of them are light, easy to handle and cheap comparing to engine scooter. Since the entrance barrier is low that various models made by various industries appeared on the market in a sudden. Few of them were profitable because price and volume dominated the market. By the end they lost market due to poor quality very quick. However, they are electrically driven, no direct emission, low energy consuming, environmental friendly product. If they can be managed by road regulation, there is no reason to ban against them on road. Taiwan makers proposed rules for such vehicles by calling them "Small Light Motorcycle" as a new category. Under this category vehicle must not exceed $60 \mathrm{~kg}$ of weight, $30 \mathrm{~km} / \mathrm{h}$ of top speed and $1 \mathrm{~kW}$ of motor output (detail rule is shown in Table 2).

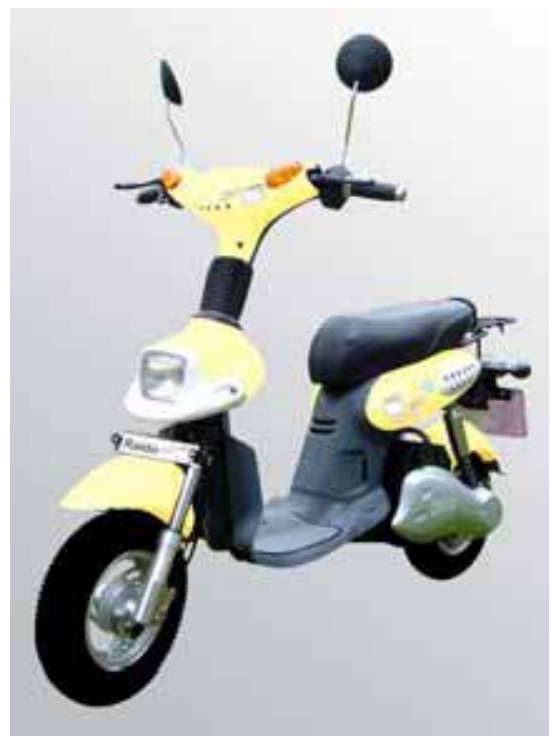

Figure 4: A typical fancy small light electric scooter made by Raido

Table 2 Draft regulation of "Small Light Motorcycle"

\begin{tabular}{|c|c|}
\hline Item & \begin{tabular}{|l} 
Regulation (Draft only) \\
\end{tabular} \\
\hline Dimension & $\begin{array}{l}\text { Length }<2.5 \mathrm{~m}, \text { width }<1 \mathrm{~m}, \\
\text { height }<2 \mathrm{~m}\end{array}$ \\
\hline $\begin{array}{l}\text { Stand stability and } \\
\text { reliability }\end{array}$ & $\begin{array}{l}\text { Stability test of side stand and } \\
\text { middle stand } \\
-10000 \text { times durability kickoff } \\
\text { test for each stand } \\
-15000 \text { times durability kickoff } \\
\text { test for vehicle equipped only } \\
\text { one stand }\end{array}$ \\
\hline Weight & $<60 \mathrm{~kg}$ \\
\hline Nominal voltage & $<48 \mathrm{~V}$ \\
\hline Motor power outpu & $<1 \mathrm{~kW}$ \\
\hline Speed & $<30 \mathrm{~km} / \mathrm{h}$ \\
\hline Tire & $4.10 / 3.50 * 5 "$ \\
\hline $\begin{array}{l}\text { Frame fatigue } \\
\text { strength }\end{array}$ & $\begin{array}{l}\text { Under specified load, } 5.5 \sim 10 \mathrm{~Hz} \text {, } \\
2 \mathrm{G} \text { after } 70000 \text { cycles vibration, no } \\
\text { rupture }\end{array}$ \\
\hline License plate & Required \\
\hline Others & $\begin{array}{l}\text { Front and rear light, horn, turning } \\
\text { and braking signs, license plate } \\
\text { light, rear refractive sign.... }\end{array}$ \\
\hline
\end{tabular}

Most important of all, the youngsters of age between 16 and 18 will be allowed to drive it by passing written examination, some elderly people who are not able to handle engine scooters may handle them easier, especially in suburb or rural area while driving private passenger cars are not attainable easily. Besides, many pros support this viewpoint:

- Heavier than bike, smaller than bike 
- With speed limit, even lower than some bike speed, easy to start up, comparably safe on road driving

- With standard front and rear light, brake light and direction sign, comparably safe than bike

- Easy to maintain stability when stop without getting off the vehicle

- Require helmet while riding bike is not mandatory to wear helmet in Taiwan

- Public transportation become more and more accessible, traditional motorcycle population is decreasing, personal mobility tends to be lighter and more convenient for short range commuting

- If bike can run on road, why not small light ES

The draft regulation is now under review in MOTC. The major counterview is safety issue since general public don't use bike as commuting vehicle in Taiwan, it is considered dangerous to have many low speed, small size vehicles on road during rush hour which are driven by young and elderly generation! They had better stay in restricted or scenic area. Electric scooter such as Yamaha Passol having higher speed of over $40 \mathrm{~km} / \mathrm{h}$ may be more acceptable.

\subsubsection{Fleet Demonstration[5]}

Four types of small light electric scooter were chosen in a five-month fleet demonstration held in Kinmon Island last year to investigate customer acceptance and vehicle reliability. Five sets of each model were driven by a hundred person-months as daily commuting vehicles. Each model was scored by its performance of top speed, acceleration, climb ability and range per charge. Every test driver was asked his (her) comment in the beginning and end of each test driving month. Table 3 shows the general conclusion. It is of no doubt the performance is not satisfied. 67 of 100 are not willing to buy, the average price awareness is around USD400. Obviously small light electric scooter is not accepted by most consummers, the performance cost ratio doesn't meet customer requirement.

Table 4 Comments made by the test drivers

\begin{tabular}{|c|c|}
\hline item & comment \\
\hline Speed & Between average and not satisfactory \\
\hline Start up & Between satisfactory and average \\
\hline Climb ability & Between average and not satisfactory \\
\hline Range & Between satisfactory and average \\
\hline Weight & Between satisfactory and average \\
\hline $\begin{array}{l}\text { Overall } \\
\text { satisfaction }\end{array}$ & Between satisfactory and average \\
\hline \begin{tabular}{|l} 
Price \\
awareness
\end{tabular} & NTD9167 18344, 13126 in average \\
\hline Willing to buy & 29 yes, 67 no, 4 no answer \\
\hline $\begin{array}{l}\text { General } \\
\text { comments }\end{array}$ & $\begin{array}{l}\text { - Too slow } \\
\text { - No fuel gage or gage not dependable } \\
\text { - Quiet and light } \\
\text { - Mostly become worse after one } \\
\text { month test drive }\end{array}$ \\
\hline
\end{tabular}

Renting light vehicle business in scenic area is quite popular around Taiwan and peripheral islands. Most of them tend to use bike, electric bike or electric scooter. The electric scooter makers find it's even more profitable than selling them to individual customer. The fleet demonstration this year is to experiment a renting business model with battery swap scenario.

\subsubsection{Exhibition and Conference}

There are four activities already become regular every year are relating to electric scooter business which are (1) International Light Electric Vehicle Conference (Figure 5 shows 2006 conference) in parallel with Taipei Cycle Show takes place in March is focusing on worldwide market trend, speaking in English, (2) Light Electric Vehicle Exhibition, a display area is dedicated for LEV in Taipei Cycle Show, (3) Taiwan Electric Vehicle Symposium (TEVS) is focusing on technology trend takes place in August, speaking in Chinese, (4) Electric Vehicle Carnival is an wide open area exhibition with ride and drive and performing stage takes place in September or October.

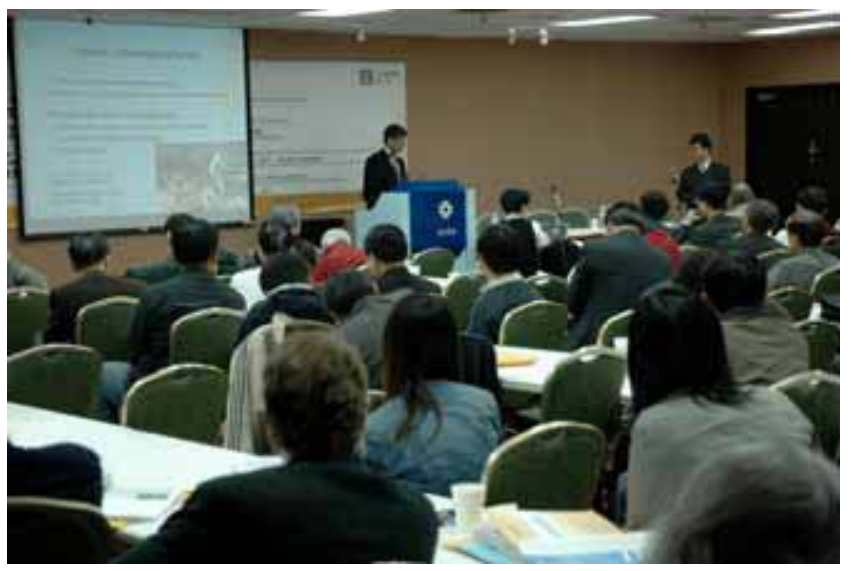

Fig. 52006 Taipei International Light Electric Vehicle Conference

\subsection{Private Segment Development Works}

\subsubsection{Scooter Hybridizes Engine and Battery}

E-TON (http://www.e-ton.com.tw), as an engine, auto component, electric scooter and ATV maker with strong will in energy and electric vehicle business development, is currently developing a parallel hybrid electric scooter which owns a $100 \mathrm{cc}$ four stroke engine and a $48 \mathrm{~V}$ battery motor system. The two power trains can deliver 6.5 and $3 \mathrm{hp}$ respectively. Vehicle weighs $120 \mathrm{~kg}$ and the target speed is $75 \mathrm{~km} / \mathrm{h}$. There are six operating modes including (1) stopping mode, (2) low speed mode, (3) normal driving and charging mode, (4) high speed cruising mode, (5) heavy acceleration mode and (6) braking and charging mode. Figure 6 shows heavy acceleration mode. It is expected to launch in middle of next year at a target price around USD1600 which is considered not expensive at such technological level. 


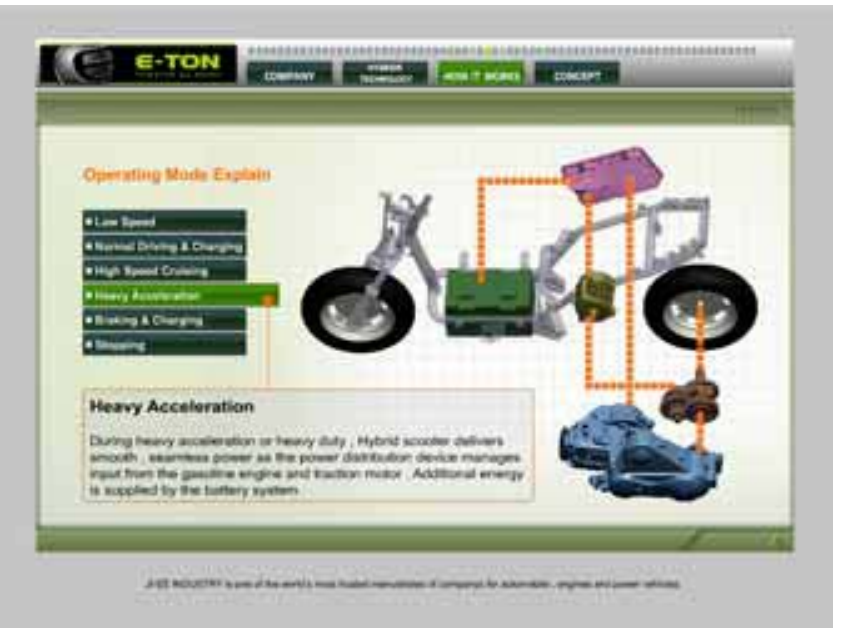

Fig. 6 One of E-TON hybrid scooter operating modes

\subsubsection{Scooter Hybridizes Fuel Cell and Battery}

APFCT (Asia Pacific Fuel Cell Technologies, http://www.apfet.com) has a primary business to commercialize polymer electrolyte membrane fuel cells. It is futuring to be provider of fuel cell stacks and systems, to enter commercialization of fuel cell with scooter engines and mobile power generators, to develop safe and convenient metal hydride hydrogen storage and distribution system. A project partly sponsored by government is to develop a parallel hybrid scooter in which a $28 \mathrm{~V}$ PEMFC system can deliver over $1.5 \mathrm{~kW}$ peak power and a $36 \mathrm{~V}$ high power lithium battery pack is served as power buffer whenever starting up or heavy load is required. There is a converter between two power systems to boost voltage of fuel cell up to $36 \mathrm{~V}$. Refueling is easily done by swapping the metal hydride hydrogen canisters as shown in figure 7 , therefore, it needs not charge infrastructure. The target speed of the vehicle is $60 \mathrm{~km} / \mathrm{h}$. A fleet of forty scooters will be put into demonstration with the help of China Petroleum Corporation to set up refueling station in specific area in 2007 .

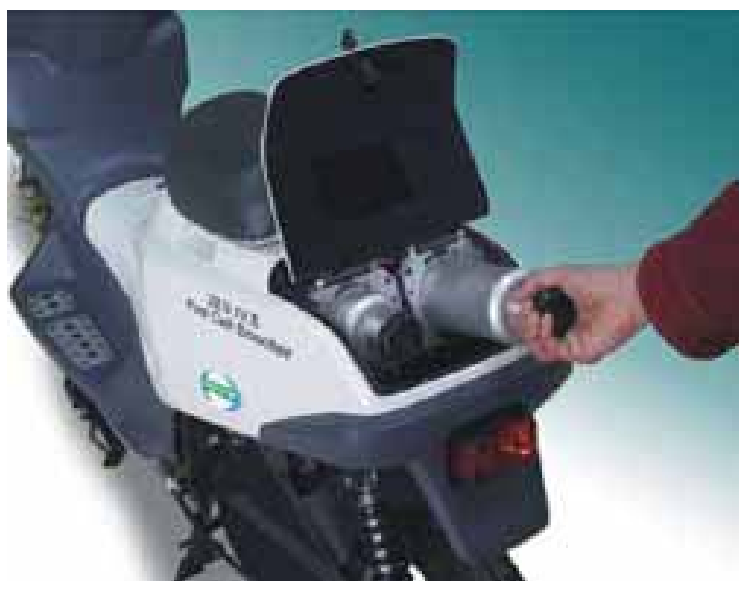

Fig. 7 Metal hydride hydrogen canisters are swappable on the rear of scooter designed by APFCT

\subsubsection{Scooter Hybridizes Two Battery Systems}

WIZ Energy Technology (http://www.wize.com.tw) patented a dual battery system for electric scooter which came from the idea to take benefits of both lead acid battery and lithium battery. Lead acid battery, served as traction resource is cheap and not movable, lithium battery, served as charging resource has long cycle life and is portable (Figure 8). A steady output converter between two battery systems is continuously drawing energy from lithium battery pack and injecting into lead acid battery or providing power to the motor driving system directly if road load is light and lead acid battery is full. Lithium battery pack is designed to be movable can be charged in office or at home, on board or off board. The benefits are:

- Lead acid battery is always staying in fully charged if scooter is not used overly for long distance driving, it can last longer.

- Output power of lithium battery is steady and low, it is not necessary to use power type battery which is more expensive in $\mathrm{Wh}$ calculation base, battery can last longer, too.

- Dual indication of battery SOC gives driver a more precise estimation of range, the SOC of lithium pack descends first and then the lead acid pack. Driver can be aware of charge requirement when charge battery runs out of energy.

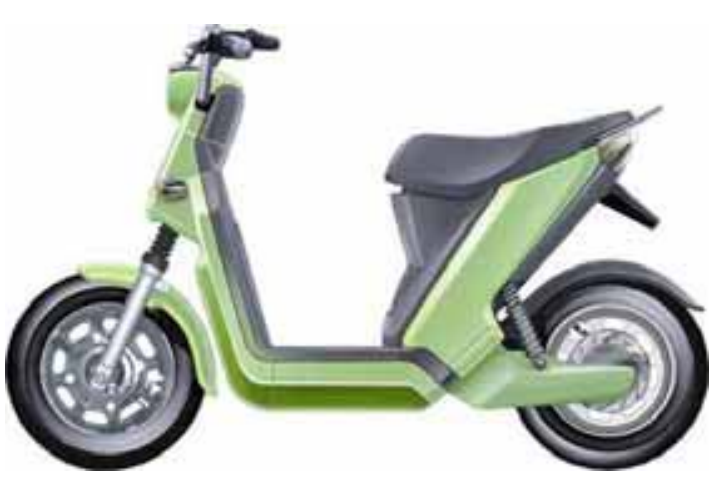

Fig. 8 A dual battery electric scooter designed by WIZ Energy Technology

\section{CONCLUSIONS}

As oil price rises to a historical highest level and is expected to be even higher in the future, people start to think of using alternative way of commuting. Electric scooter can be one of the solutions. Thanks to the continuous improvement of vehicle and battery technologies, the scooter makers are thinking really market viable strategy. Those hybrid concepts solve charging infrastructure or performance issues still need further fleet test or market investigation to get customer's awareness. Government is also stimulated by the prosperous market in China and starting to outline the subsidiary policy again. This step must be deliberate and cautious to avoid from repeating the failure make in last decade. 


\section{ACKNOWLEDGEMENT}

Special thanks to Bureau of Energy (BOE) and Industry Development Bureau (IDB), Ministry of Economic Affairs, who sponsor the research of the battery technology and promotion of electric vehicles.

\section{REFERENCES}

[1] Jen-Swei Kuo: "Development of Electric Scooter in Taiwan", EVS-16, 1999.

[2] Jen-Swei Kuo: "Feasibility Survey of ES Battery Swapping \& Leasing Business", EVS-16, 1999.

[3] Pao-Chuan Lin etc.: "A Fully Digital Rapid Charger for Electric Scooters", EVS-18, 2001.

[4] B.M. Lin: "Perspective of LEV Industry in Taiwan", Light Electric Vehicle International Conference, Vol. 2006, pp. 223-237, 2006.

[5] B.M. Lin: "The Promotion of Electric Vehicles in Taiwan”, 2006 Taipei Power Forum, Session I-EV, 2006.

\section{BIOGRAPHIES}

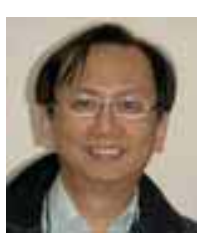

*Bing Ming Lin, Manager, EV Battery Program, Material and Chemical Research Laboratories of Industrial Technology Research Institute. Mr. Lin received bachelor degree from Chung Yuan University majored in mechanical engineering has worked in Industrial Technology Research Institute (ITRI) for more than twenty years.

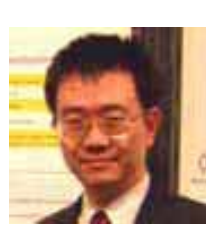

**Mo Hua Yang, Ph.D. Senior Researcher

Industrial Technology Research Institute, Material and Chemical Research Laboratories,

Dr. M.H. Yang received his Ph.D. degree from Catholic University of Louvain in Belgium. He has worked at Industrial Technology Research Institute (ITRI) in Li-ion battery project since 1997. He is now the special assistant of MCL, ITRI.

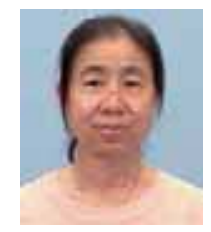

***Theresa Suen, Administration, EV Battery Program, Material and Chemical Research Laboratories of Industrial Technology Research Institute. Ms. Suan received B. S. degree inAccounting from National Cheng Kung University has worked in ITRI for over fifteen years. 